\title{
The Potential of BASF NPK Fertilizers Associated with Trichoderma viride Fertilizer on the Growth and Production of Shallots (Allium ascalonicum L.)
}

\author{
Savitri $^{*}$, Usnawiyah ${ }^{2}$ \\ ${ }^{I}$ Department of Agrotechnology, Faculty of Agriculture, Abulyatama University \\ Jl. Blang Bintang Lama, KM 8,5 Lampoh Keude Kutabaro, Aceh Besar 24415 \\ ${ }^{2}$ Department of Agroecotechnology, Faculty of Agriculture, Universitas Malikussaleh \\ Jl. Tgk. Cot Nie Reuleut, Muara Batu, Aceh Utara 24355 \\ *Corresponding author: vitrimuis044@gmail.com
}

\section{ARTICLE HISTORY \\ Received : 11 February 2019 \\ Revised : 10 March 2019 \\ Accepted : 23 April 2019}

\section{KEYWORDS}

NPK BASF Fertilizers

Trichoderma viride

Allium ascalonicum

Growth

Production

\begin{abstract}
This research was carried out on the Experimental Garden, Faculty of Agriculture, Abulyatama University, Aceh Besar. This research was conducted from September $26^{\text {th }}$ to December $2^{\text {nd }}, 2017$. This research was assigned in a Completely Randomized Design (CRD) factorial with 3 replications. There were 12 combinations of treatments and 36 units of experiments. The first factor was Trichoderma viride Fertilizer (T) which consists of 4 levels: $\mathrm{T} 0=0$ gram $/$ polybag, T1=50 g/polybag, T2=100 g/polybag, $\mathrm{T} 3=150 \mathrm{~g} /$ polybag. The second factor was BASF NPK Fertilizers (N) consists of 3 levels: $\mathrm{N}=0 \mathrm{~g} /$ polybag, $\mathrm{N} 1=3 \mathrm{~g} /$ polybag, $\mathrm{N} 2=6 \mathrm{~g} /$ polybag. The parameters observed in this study were plant height, bulb diameter, wet weight and dry weight of bulbs. The results revealed that various doses of $T$. viride fertilizer increased the plant height respectively at 20 and 40 days after planting. Surprisingly, there was no significant difference in plant height at 60 days after planting. The best results for the application of T. viride fertilizer were found in T1 (50 g/polybag). This fertilizer also exhibited insignificant results in bulb diameter, wet weight and dry weight of bulbs at all observed ages. The application of BASF NPK fertilizers did not significantly affect all observed parameters (plant height, bulb diameter, wet weight and dry weight of onion bulbs). There were no interactions due to application of T. viride fertilizer and BASF NPK fertilizers to all observed parameters.
\end{abstract}

This is an open access article under the CC-BY-SA license.

\section{INTRODUCTION}

Shallots (Allium ascalonicum L.) variety Tuk-Tuk are a horticultural commodity which is classified as useful and important spice and herbs which often used as a complement or food flavoring in cuisines and source of vitamins, minerals, protein, fat, and carbohydrates (Sufyati et al., 2006; Yetti and Evawani, 2008) Besides, shallots can also be used as traditional medicines due to its anti-cancer, anti-inflammatory, antifungal and antimicrobial activities (Estu et al., 2007; Mahmoudabadi and Nasery, 2009; Rattanachaikunsopon and Phumkhachorn, 2009; Motlagh et al., 2011; Amin et al., 2018, Ng et al., 2018). In addition, this plant is also beneficial in curing constipation, controlling blood pressure, lowering cholesterol, reducing diabetes and reducing the risk of liver disorders (Hakim, 2010; Moradabadi et al., 2013).

Shallots (variety Tuk-Tuk) are important and valuable commodity which has a high value and demand in the market. The center of shallot production and its sellers/businessmen are needed to be more improved considering the increasing of growth population and its demand of shallots, enabled this commodity to become very prospective (Estu et al., 2007). For its nutritional content, $100 \mathrm{~g}$ of shallots contain about $80-85 \%$ water, $1.5 \%$ protein, $0.3 \%$ fat and $9.2 \%$ carbohydrate and other ingredients such as iron, minerals, potassium, phosphorus, ascorbic acid, vitamins B and C (Wibowo, 2001). The production and yield of shallot plants needs to be increased due to abundance natural resources and 
promising opportunity in the market (Rukmana, 1994). The best amount of yield if shallots production can reach up to 10-21 tons/ha. Due to essential requirement of shallot every year, so its production must be increased. There is one effort to obtain optimum yield of shallots, by reducing the use of chemical fertilizers and replace them with biocontrol agents to improve soil fertility, so that the plant can grow well. Fungi Trichoderma is well known as one of biocontrol agents which is capable to decompose organic matters and enhance the nutrients in the soil for plant growth (Epa et al., 2000).

It is undeniable that many farmers are not aware about soil fertility when talking about plant growth. They are more focused on macro and micro nutrients available in soil. As a matter of fact, biological factors such as biocontrol agents (Genus Trichoderma) are also play an important role in supporting the plant growth. Various organic compounds produced by this fungus in the process of decomposition of various organic materials play a role in spurring growth, accelerating flowering processes and inhibiting the appearance and the growth of pathogens (Laurensius, 2012). Trichoderma enabled to release $\mathrm{P}$ that is unavailable in the soil. This Trichoderma functions not only as a biocontrol agent and stimulator of plant growth, but also it increases nutrients for plants and protects the soil from diseases, and controls diseases such as soft rot in tubers and wilt diseases that often attack plants (Berg, 2009; Hermosa et al., 2012)

Soil fertility is one of the factors that determine the plant production and yield. The use of chemical fertilizers can also enrich the nutrients in the soil besides the application of biofertilizer. This is in accordance with research of Sutedjo (2010). He stated that to enhance the availability of nutrients in the soil, it can be done by applying NPK fertilizers. Nutrients of Nitrogen $(\mathrm{N})$, phosphorus (P) and Potassium (K) are macro nutrients which are very important for plant growth (Novizan, 2002).

NPK BASF fertilizers are a complex fertilizer containing $15 \% \mathrm{~N}, 15 \% \mathrm{P}_{2} \mathrm{O}_{5}$ and $15 \% \mathrm{~K}_{2} \mathrm{O}$. The application of this fertilizer can guarantee balanced nutrients in soil. $\mathrm{N}, \mathrm{P}$ and $\mathrm{K}$ are macro nutrients which been required by plants. Nitrogen $(\mathrm{N})$ plays an important role in vegetative growth, phosphor (P) increases the development of plant roots, while potassium $(\mathrm{K})$ can improve both quality and quantity of plants (Lingga, 1986). Regarding to the description above, the proper dose of Trichoderma fertilizer and NPK BASF fertilizers are unknown. The further research needs to be done to examine this problem. This research is aimed to examine the growth and development of shallots (Allium ascalonicum L.) by applying Trichoderma viride and NPK BASF fertilizers.

\section{MATERIALS AND METHODS}

This research was conducted at Experimental Garden, Faculty of Agriculture, Abulyatama University, Banda Aceh, from 10 September to 5 December 2018. Materials used in this research: shallot seeds, obtained from the local farming shop in Banda Aceh, biofertilizer (T. viride) obtained from Tangerang, West Java, initial fertilizer (manure) 20 tons/ha. The tools used were knives, polybags (10 kg), hoes, buckets, bolts, watering cans, scissors, hand sprayers, cameras, rulers, scales, planks, and stationery.

\subsection{Research preparation}

\section{a. Preparation of planting media}

The weeds and rubbish needed to be cleaned before preparing the media. Planting media was prepared with arable soil and there were no weeds on it. The soils needed to be sieved (12 mesh) to homogenize the soil. Then, the soil was mixed with manure as an initial fertilizer (100 g/polybag) and then the mixture was placed in polybags $(10 \mathrm{~kg})$.

\section{b. Seed Preparation}

Before sowing the seeds, the tools for sowing needed to be prepared such as baskets, soil, manure, roasted husk charcoal (1:1:1) and then the seeds were placed into the baskets and then transferred to polybags.

\section{c. Sowing the shallot seeds}

To place the seeds, holes on the surface of soil needed to be made, using wooden sticks. After that, 3 seeds were placed into the holes and covered the holes with soil. The bulbs should not be placed too deep to avoid the bulbs to be damaged.

\section{d. Fertilization}

Initial fertilizers were applied before planting. Trichoderma fertilizers were applied when the land was cultivated by mixing fungus $T$. viride with soil according to the experiments tested. BASF NPK fertilizers were applied at 3,23 and 43 days after planting by dissolving these fertilizers according to the doses tested, so that the plants can get nutrients continuously resulted in optimal production.

\section{e. Plant maintenance}

Plant maintenance included watering the plants, weeds maintenance, pests and diseases control, harvesting, and drying the yield.

\subsection{Observations}

\section{a. Plant height $(\mathrm{cm})$}

Plant height was measured from the base of the plant, above the ground to the highest leaf tip. Observation of plant height was done at 20, 40 and 60 days after planting.

\section{b. Bulb diameter (cm)}

One plant required only one bulb. The bulb diameter is calculated using calipers.

\section{c. Wet weight of bulbs (g)}

The bulbs were weighed using weighing scales after being cleaned from the dirt.

\section{d. Dry weight of bulbs (g)}

The bulbs were weighed 4-5 days after being dried. 


\subsection{Statistical Data Analysis}

Data were subjected to Analysis of Variance (ANOVA) where significant differences existed means were separated using Tukey Test Tukey's HSD) at 0.05 probability level.

\section{RESULTS AND DISCUSSIONS}

\section{Effect of Application of Trichoderma viride fertilizer to shallot plants}

\section{a. Plant height $(\mathrm{cm})$}

The results of plant height were illustrated in Table 1. The results of ANOVA showed that the application of Trichoderma viride fertilizer significantly increased the plant height at 20 and 40 days after planting (DAP), but it had no effect at 60 days after planting. The average height of shallots at 20, 40 and 60 days after planting was shown in Table 1.

Table 1. Average height of shallot plants treated with $T$. viride

\begin{tabular}{lccc}
\hline \multirow{2}{*}{\multicolumn{1}{c}{ Doses }} & \multicolumn{3}{c}{ height $(\mathrm{cm})$} \\
\cline { 2 - 4 } & 20 DAP & 40 DAP & 60 DAP \\
\hline $\mathrm{T}_{0}=0$ g/polybag & $27.79 \mathrm{~b}$ & $48.96 \mathrm{a}$ & $54.88 \mathrm{a}$ \\
$\mathrm{T}_{1}=100 \mathrm{~g} /$ polybag & $33.43 \mathrm{c}$ & $58.52 \mathrm{~b}$ & $61.28 \mathrm{a}$ \\
$\mathrm{T}_{2}=150 \mathrm{~g} /$ polybag & $28.24 \mathrm{bc}$ & $53.39 \mathrm{ab}$ & $60.22 \mathrm{a}$ \\
$\mathrm{T}_{3}=200 \mathrm{~g} /$ polybag & $22.39 \mathrm{a}$ & $47.40 \mathrm{a}$ & $57.88 \mathrm{a}$ \\
\hline Tukey's HSD 0.05 & 5.34 & 8.41 & 7.50 \\
\hline
\end{tabular}

Means in the same rows followed by the same letters do not differ significantly $(\mathrm{P}=0.05)$. $\mathrm{DAP}=$ days after planting.

Table 1 demonstrated that the highest height found at 20 and 40 days after planting with dose $100 \mathrm{~g} /$ polybag. It could be caused by the application of $100 \mathrm{~g} /$ polybag has stimulated the growth of apical meristem, where this tissue continuously developed throughout its life cycle so that it is also stimulate the plant height. T. viride also provided nutrients simultaneously in order plants to get available nutrients continuously. $T$. viride has been reported to be a plant-promoting growth fungus, enabled plants to grow well due to available nutrients in soil. Also, the existence of this astfungus in soil suppresses the pathogen's growth (Hersanti, 2000). Unfortunately, the appearance of this bio-control agent did not affect the apical meristem at 60 days after planting (Table 1).

\section{b. Bulb diameter $(\mathrm{cm})$}

The results of bulb diameter were given in Table 2 . ANOVA results revealed that there was no significant difference to diameter of plants treated with $T$. viride.

Table 2. Average diameter of bulbs the plants treated with $T$. viride.

\begin{tabular}{cc}
\hline \multicolumn{1}{c}{ Doses } & Bulb diameter $(\mathrm{cm})$ \\
\hline T0 $=0$ g/polybag & $4.72 \mathrm{a}$ \\
T1 $=100$ g/polybag & $5.27 \mathrm{a}$ \\
T2 $=150$ g/polybag & $5.43 \mathrm{a}$ \\
T3 $=200$ g/polybag & $5.10 \mathrm{a}$ \\
\hline Tukey's HSD 0.05 & 0.96 \\
\hline
\end{tabular}

Means in the same rows followed by the same letters do not differ significantly $(\mathrm{P}=0.05)$. not significantly increase the bulb diameters. It can be said that the doses tested were inadequate to plants to develop well and to have optimum crop yield. The application of doses tested apparently could not stimulate the lateral cambium of the shallot plants, which functioned to widen the diameter of bulbs.

\section{c. Wet weight of bulbs}

The results of wet weight of bulbs were illustrated in Table 3. The application of T. viride was insignificant to wet weight of bulbs.

Table 3. Average wet weight of bulbs of the plants treated with T. viride

\begin{tabular}{lc}
\hline \multicolumn{1}{c}{ Doses } & Wet weight $(\mathrm{g})$ \\
\hline $\mathrm{T}_{0}=0 \mathrm{~g} /$ polybag & $45.78 \mathrm{a}$ \\
$\mathrm{T}_{1}=100 \mathrm{~g} /$ polybag & $46.83 \mathrm{a}$ \\
$\mathrm{T}_{2}=150 \mathrm{~g} /$ polybag & $54.67 \mathrm{a}$ \\
$\mathrm{T}_{3}=200 \mathrm{~g} /$ polybag & $44.67 \mathrm{a}$ \\
\hline Tukey's HSD 0.05 & 18.28 \\
\hline
\end{tabular}

Means in the same rows followed by the same letters do not differ significantly $(\mathrm{P}=0.05)$.

Table 3 described that that the application of $T$ viride also gave insignificant results to the wet weight of bulbs at all treatment tested. This could be because the working system of $T$. viride is influenced by the environment. Gajdar et al (2006) reported that fungi's growth is strongly influenced by environmental factors, such as substrate, humidity soil acidity. Marianah (2013) explained that Trichoderma fungus can develop well if the humidity reaches $80-90 \%$. Unfortunately, we found that the conditions at the time of the research was conducted, was unable to support the development of the Trichoderma fungus so that it gave insignificant results to the development of plants.

\section{d. Dry weight of bulbs (g)}

The results of dry weight of bulbs were given in Table 4 . It showed that the application of $T$. viride did not significantly increase the dry weight of bulbs.

Table 4. Average dry weight of bulbs of the plants treated with T. viride

\begin{tabular}{ll}
\multicolumn{1}{c}{ Doses } & \multicolumn{1}{c}{ Dry weight $(\mathrm{g})$} \\
\hline $\mathrm{T}_{0}=0 \mathrm{~g} /$ polybag & $33.72 \mathrm{a}$ \\
$\mathrm{T}_{1}=100 \mathrm{~g} /$ polybag & $46.83 \mathrm{a}$ \\
$\mathrm{T}_{2}=150 \mathrm{~g} /$ polybag & $46.89 \mathrm{a}$ \\
$\mathrm{T}_{3}=200 \mathrm{~g} /$ polybag & $40.78 \mathrm{a}$ \\
\hline Tukey's HSD 0.05 & 14.05
\end{tabular}

Means in the same rows followed by the same letters do not differ significantly $(\mathrm{P}=0.05)$.

The data in Table 4 indicated that the application of this biocontrol agent gave insignificant result to the dry weight of shallot bulbs. Hersanti et al (2000) found that $T$. viride was not only play a role as biocontrol agent, but also as biofertilizer which its appearance could restore soil and land structures. This restored soil enabled plants to have better yield in the next planting season (Ajmi, 2011). 


\section{Effect of application of BASF NPK fertilizers to shallot plants}

a. Plant height $(\mathrm{cm})$

The results of the plant height were illustrated in Table 5. ANOVA analysis revealed that the application BASF NPK fertilizers did not significantly increased the plants' height

Table 5. Average height of plants of plants treated with BASF NPK fertilizer

\begin{tabular}{cccc}
\hline \multirow{2}{*}{ Doses } & \multicolumn{3}{c}{ Average height $(\mathrm{cm})$} \\
\cline { 2 - 4 } & $20 \mathrm{DAP}$ & $40 \mathrm{DAP}$ & $60 \mathrm{DAP}$ \\
\hline $\mathrm{T}_{0}=0 \mathrm{~g}$ /polybag & $27.95 \mathrm{~b}$ & $52.88 \mathrm{a}$ & $60.77 \mathrm{a}$ \\
$\mathrm{T}_{1}=3$ g/polybag & $27.73 \mathrm{c}$ & $52.18 \mathrm{~b}$ & $58.83 \mathrm{a}$ \\
$\mathrm{T}_{2}=6 \mathrm{~g}$ /polybag & $28.21 \mathrm{bc}$ & $51.17 \mathrm{ab}$ & $5610 \mathrm{a}$ \\
\hline Tukey's HSD 0.05 & 6.55 & 10.33 & 9.21 \\
\hline
\end{tabular}

Means in the same rows followed by the same letters do not differ significantly $(\mathrm{P}=0.05)$.

The data in Table 5 demonstrated the application of BASF NPK fertilizers at 20, 40 and 60 days after planting (DAP) did not have significant difference to the height of shallot plants. This could be because of the metabolite process in the plants which contributed to the growth of plants. Vegetative growth of plants requires large amounts of $\mathrm{N}$ to help the cells to growth and divide (Sasongko, 2010). Plants need adequate nutrients in the beginning of their growth, to facilitate the metabolic process in the vegetative phase. This is related to the requirements of macro and micro nutrients in the optimum quantity to encourage the plants to growth and produce optimum yield.

\section{b. Bulb Diameter (cm)}

The results of bulb diameter were given in Table 6 . The data analysis showed that the application of BASF NPK fertilizers did not significantly increase the bulb diameter of shallots plants.

Table 6. Average of bulb diameter of plants treated with BASF NPK fertilizers

\begin{tabular}{cc} 
NPK fertilizers & Bulb diameter $(\mathrm{cm})$ \\
\hline $\mathrm{T}_{0}=0 \mathrm{~g} /$ polybag & $4.72 \mathrm{a}$ \\
$\mathrm{T}_{1}=3 \mathrm{~g} /$ polybag & $5.27 \mathrm{a}$ \\
$\mathrm{T}_{2}=6 \mathrm{~g} /$ polybag & $5.43 \mathrm{a}$ \\
\hline Tukey's HSD 0.05 & 1.18
\end{tabular}

Means in the same rows followed by the same letters do not differ significantly $(\mathrm{P}=0.05)$.

Table 6 revealed that the application of BASF NPK fertilizers did not increase the sizes of bulb diameter. It can be assumed that the doses applied to the plants were inappropriate. Kristiani (2014) reported that BASF NPK should be applied appropriately. Improper application of fertilizer can destroy the structure and chemical contents of soil because of its ability to absorb the nutrients rapidly, resulted in poor nutrients soils. If there are inadequate fertilizers applied in soil, it could disable soil to have sufficient nutrition to support the growth of the plants.

\section{c. Wet weight of bulbs (g)}

The results were illustrated in Table 7. ANOVA indicated that there was no difference of wet weight of bulbs due to the application of BASF NPK fertilizers.

Table 7. Average wet weight of bulbs of plants treated with BASF NPK fertilizers

\begin{tabular}{lc}
\hline \multicolumn{1}{c}{ Doses } & Wet weight $(\mathrm{g})$ \\
\hline $\mathrm{T}_{0}=0 \mathrm{~g} /$ polybag & $47.63 \mathrm{a}$ \\
$\mathrm{T}_{1}=3 \mathrm{~g} /$ polybag & $46.08 \mathrm{a}$ \\
$\mathrm{T}_{2}=6 \mathrm{~g} /$ polybag & $50.25 \mathrm{a}$ \\
\hline Tukey's HSD 0.05 & 22.45 \\
\hline
\end{tabular}

Means in the same rows followed by the same letters do not differ significantly $(\mathrm{P}=0.05)$.

The results in Table 7 described that the application of BASF NPK fertilizers did not affect the wet weight of bulbs. It happened could be because the fertilizers were applied not at right time and in the right quantities. The application of fertilizers in this research was based on the results of soil testing. This action had lesser beneficial to the plants specifically and environment generally (Sabihan, 1996). NPK fertilizers have been known to have advantages and disadvantages, so more information is needed on the types of fertilizer that appropriate for the growth of shallot plants (Novizan, 2002).

\section{Dry weight of bulbs (g)}

The results of dry weight of bulbs were described in Table 8. The results showed that there is no significant difference to the dry weight of bulbs due to the application of BASF NPK fertilizers.

Table 8. Average of dry weight of bulbs of plants treated with BASF NPK fertilizers.

\begin{tabular}{lc}
\hline \multicolumn{1}{c}{ Doses } & Dry weight $(\mathrm{g})$ \\
\hline $\mathrm{T}_{0}=0 \mathrm{~g} /$ polybag & $35.58 \mathrm{a}$ \\
$\mathrm{T}_{1}=3 \mathrm{~g} /$ polybag & $43.25 \mathrm{a}$ \\
$\mathrm{T}_{2}=6 \mathrm{~g} /$ polybag & $44.33 \mathrm{a}$ \\
\hline Tukey's HSD 0.05 & 71.25 \\
\hline
\end{tabular}

Means in the same rows followed by the same letters do not differ significantly $(\mathrm{P}=0.05)$.

Results in Table 8 showed that the application of BASF NPK fertilizers gave insignificant results to dry weight of bulbs. This might happened due to environmental factors such as inadequate process of photosynthesis resulted from lack of sunlight (Paelongan et al., 2004).

\section{CONCLUSIONS}

1. The application of various doses of T. viride fungus as fertilizer significantly increased the plant height at 20 and 40 days after planting (DAP), but there was no significant difference at 60 days after planting. The best doses for $T$. viride were found in T1 (50 $\mathrm{g} /$ polybag). The application of $\mathrm{T}$. viride did not affect the bulb diameter, wet weight, and dry weight of shallot bulbs at all treatments.

2. The application of BASF NPK fertilizers did not gave significant results to all variables observed: plant height, bulb diameter, wet weight, and dry weight of 
shallot bulbs.

3. There is no interaction between the application of $T$. viride fertilizer and BASF NPK fertilizers to all variables observed.

\section{REFERENCES}

Ajmi, S.R. 2011. Efficacy of Trichoderma as biofungicide against pathogens on Taro plants (written in Indonesian language). Script. Jurusan Biologi. Fakultas Matematika dan Ilmu Pengetahuan Alam. Universitas Semarang.

Amin, M, Asie V, M., Mohsen H., and Saeed K. 2018. Antibacterial and anticancer activity of a bioflavonoid fractionated from Allium Ascalonicum. Journal of Paramedical Sciences, 9(3): 1-8.

Berg, G. 2009. Plant-microbe interactions promoting plant growth and health: perspectives for controlled use of microorganisms in agriculture. Applied Microbiology and Biotechnology, 84(1): 11-18.

Epa., 2000. Trichoderma rifai Strin T-39. Technical Document. Kanisius, Yogyakarta.

Estu, Rahayu dan Barlian Va, Nur. 2007. Onions (Written in Indonesian language). Penebar Swadaya, Jakarta.

Gadjar, Indrawati, Sjamsulrijal, W., dan Aryanti. 2006. Basic And Applied Mycology (Written in Indonesian language). Yayasan Obor. Indonesia, Jakarta.

Hakim, R.D. 2010. Effect of Shallot (Allium ascalonicum L.) on level of LDL-cholesterol serum in Wistar rats with hyperlipidemia (Written in Indonesian language). Script. Fakultas Kedokteran. Universitas Diponegoro, Jawa Timur.

Hermosa, R., Ada, V., Ilan, C and Enrique M. 2012. Mini review: plant-beneficial effects of Trichoderma and of its genes. Microbiology, 158: 17-25.

Hersanti., Endah, Y.D., dan Luciana. 2000. The influence of Introduced fungus, Trichoderma and Efficacy of MS (M4) microorganism against wilt disease by Fusarium oxysporum on tomato plants (written in Indonesian language). Research report. Fakultas Pertanian. Universitas Padjajaran Bandung, Bandung.

Kurniadinata, O. F., Poerwanto, R., \& Susila, A. D. (2018). The Determination of Phosphor Status in Leaf Tissues to Make a Fertilizer Recommendation and Predict Mangosteen Yield. Journal of Tropical Horticulture, 1(1), 7-9.

Kristiani. 2014. The Effect of application of biofertilizer to the growth and productivity of cayenne peppers (written in Indonesian language). Jurnal Science dan Seni Pomits. Vol 2 No (1) . Surabaya.

Laurensius, L. 2012. Analysis of organic fertilizer made from bicontrol agent Trichoderma to potato plants (written in Indonesian language). Universitas Politeknik Pertanian Negeri Kupang, Kalimantan Timur.

Mahmoudabadi, A. Z and Nasery, M.K.G. 2009. Antifungal activity of shallots (Allium ascalonicum Linn. (Liliaceae), in-vitro. Journal of Medicinal Plants Research, 3(5): 450-453.

Marianah, L.2013. Analysis of application of Trichiderma sp. to the growth of soybean (written in Indonesian language). Karya Tulis Ilmiah. Balai Pelatihan Pertanian, Jambi.

Moradabadi, L., Shideh, M.K and Mohammad, F. S. 2013. Hypoglycemic Effects of Three Medicinal Plants in Experimental Diabetes: Inhibition of Rat Intestinal $\alpha$-glucosidase and Enhanced Pancreatic Insulin and Cardiac Glut-4 mRNAs Expression. Iranian Journal of Pharmaceutical Research, 12(3): 387-397.

Motlagh, H.R.M., Ali, M and Kamran, M. 2011. Anticancer and anti-inflammatory activities of shallots (Allium ascalonicum) extract. Archives of Medical Science, 7(1): 38-44.

Ng, T.S., Ley, J.L., Ban, S. 0 and Pei, P.C. 2018. Antifungal and anti-biofilm effects of shallots (Allium ascalonicum) aqueous extract on Candida albicans. Journal of Herbmed Pharmacology, 7(4): 236-242.

Novizan. 2002. The Guidelines of Effective Fertilization (Written in Indonesian language). Agro Media Pustaka. Jakarta.
Paelongan, Z.PM. Amjaya dan Elyani. 2004. Effect of application of silver and black plastic mulch and dose of manure to the growth and yield of leek plants (written in Indonesian language). Jurnal Budidaya Pertanian. Universitas Sebelas Maret. Surakarta.

Rattanachaikunsopon, P and Phumkhachorn, P. 2009. Shallot (Allium ascalonicum L.) oil: Diallyl sulfide content and antimicrobial activity against food-borne pathogenic bacteria. African Journal of Microbiology Research, 3(11) 747-750.

Rukmana, R. 1994. Cultivation of Shallots Variety Tuk Tuk (Written in Indonesian language). Kanisius. Yogyakarta.

Sufyati, Y., Said, I. A. K., and Fikrinda. 2006. The Influence of Physical Size and Number of Bulbs Per Hole on Growth and Yield of Shallots (Allium ascalonicum L.). (written in Indonesian language). Jurnal Floratek, 2: 43-54.

Wibowo, S. 2001. Cultivation of Garlic, Shallots and Onion (Written in Indonesian language). Penebar Swadaya, Jakarta.

Yetti, $\mathrm{H}$ and Evawani, E. 2009. The use of organic fertilizer and $\mathrm{KCl}$ on shallots (Allium ascalonicum L.). (written in Indonesian language). Jurnal Sagu, 7(1): 13-18. 